\title{
Bibliografija slovenskih udeležencev dosedanjih mednarodnih slavističnih kongresov (referati, komunikati, tematski bloki)
}

\author{
Alenka Šivic-Dular
}

Cobiss: 1.24

Bibliografija, ki zajema mednarodne slavistične kongrese do vključno štirinajstega leta 2008 na Ohridu, je urejena abecedno po priimkih avtorjev ne glede na raziskovalno področje. Vanjo niso vključeni v Ljubljani nedostopni povzetki s kongresov v Sofiji $(1963,1988)$ in Bratislavi (1993). - Za dolgim pomišljajem (-) je naveden bibliografski podatek o sočasni ponovni objavi (povzetku, prevodu ipd.) prej navedenega prispevka istega avtorja ali soavtorjev. - Pri posameznem avtorju si (tudi soavtorske) enote sledijo v časovnem zaporedju. $-\mathrm{MSK}=$ mednarodni slavistični kongres.

Vanda Babič, Matej Sovič in ohranjeni rokopis njegovega latinskega prevoda slovnice Meletija Smotrickega (1619) iz leta 1773 v rokopisni zbirki NUK Ljubljana, Slavistična revija 56 (2008), št. 2, 31-47. — Vanda Babič - Aleksandra Derganc, Matej Sovič i sačuvan rukopis njegovog latinskog prijevoda gramatike Meletija Smotrickog (1619.) iz 1773. godine u rukopisnoj zbirci NUK Ljubljana, MSK-14, 198-199.

Štefan Barbarič, Herder in začetki slovenske romantike, Slavistična revija 16 (1968), 231-256.

Štefan Barbarič, Pojmovanje romantike v starejši slovenski literarni zgodovini, MSK-7, 671-672.

Štefan Barbarič, Tipi slovenskega romana v dvajsetletju 1866-1885, Slavistična revija (1977), kongresna št., 117-133. — Tipološka oznaka slovenskega romana v dvajsetletju 1866-1885, MSK-8, 46.

Štefan Barbarič, Turgenjev in slovenska varianta "poetičnega realizma«, Slavistična revija 31 (1983), št. 2, 77-87. — L'influence de Tourguéniev sur la formation de la doctrine du réalisme slovène, MSK-9, $288-289$.

France Bernik, Problem Cankarjeve lirike, Slavistična revija 16 (1968), 169-202.

— Problematika literarnih zvrsti v razvoju slovenske književnosti v XIX. stoletju, MSK-6 $2,27$.

France Bernik, Roman Ivana Cankarja v luči impresionistične in simbolistične poetike, Slavistična revija (1977), kongresna št., 135-159. — Roman Ivana Cankarja v luči impresionistične in simbolistične poetike, MSK-8 $1,71$.

France Bernik, Književnost slovenske moderne v evropskem kontekstu, Slavistična revija 41 (1993), št. 1, 13-24. 
France Bernik, Kulturna identiteta v obdobju globalizacije: nevarnosti in perspektive, MSK-13, 27 (plenarno predavanje). - Kulturna identiteta v obdobju globalizacije: nevarnosti in perspektive, MSK-13 $2,192$.

France Bezlaj, Stratigrafija Slovanov v luči onomastike, Slavistična revija 11 (1958), št. 1-2, 35-56. - Stratigrafija Slovanov v luči onomastike, Južnoslovenski filolog 23 (1958), št. 1-4, 83-95.

Milena Mileva Blažić, Primerjalna analiza germanskih, romanskih in slovanskih ljudskih pravljic na primeru motiva živalskega ženina oz. živalske neveste, Slavistična revija 56 (2008), št. 2, 191-201. - Comparative analysis between German, Romanic, and Slavic models of of folk and fairy tales, MSK-14 $2,187$.

Marja Boršnik, Književna gibanja kot odsev družbenega razvoja slovenskega naroda, Slavistična revija 11 (1958), št. 1-2, 57-68.

Marja Boršnik, Stilni premiki v slovenski književnosti med klasičnim in modernim realizmom, Slavistična revija 14 (1963), 79-110.

Marja Boršnik, Problem ustvarjalnega ritma v slovenski literarni zgodovini, MSK- $8,110$.

Robert Cazinkić, Nepravi oziralni stavki in oziralna zveza v sodobnem slovenskem knjižnem jeziku, MSK-13,231.

Rada Cossutta, Romanski vplivi v govorih slovenske Istre, Slavistična revija 46 (1998), št. 1-2, 73-81. - Romanski vplivi v govorih slovenske Istre, MSK$12_{1}, 245-246$.

Rada Cossutta, Slovenski dialektološki leksikalni atlas koprske pokrajine, Slavistična revija 51 (2003), posebna št., 27-35. - Atlante lessicale dei dialetti sloveni dei Capodistriano (SDLA-Kp): tradizione e innovazione, MSK-13, 231-232.

Varja Cvetko Orešnik, On the Significant Contribution of O. N. Trubatchev to the Study of Language Relationships between Balto-Slavic and Indo-Iranian: in Memory to the Great Linguist, MSK-13, 232-233.

Jožica Čeh, Folklorni svet v liriki slovenske moderne, Slavistična revija 51 (2003), posebna št., 211-223. - Folklorni svet v liriki slovenske moderne, MSK-13, 193.

Aleksandra Derganc, The Language of Russian and Bulgarian Hagiographers in the Time of the Second South Slavic, MSK-9, 41-42.

Aleksandra Derganc, Spremembe nekaterih dvojinskih oblik in zvez v slovenščini in ruščini, Slavistična revija 41 (1993), št. 1, 209-218.

Aleksandra Derganc, Nekatere paralele v razvoju dvojine v slovenščini in lužiški srbščini, Slavistična revija 46 (1998), št. 1-2, 45-54. - Some parallels in the development of the dual in Slovene and Sorbian, MSK-12, 245-246.

Aleksandra Derganc, Nekatere razlike v rabi dovršnega oz. nedovršnega vida v ruščini in slovenščini, Slavistična revija 51 (2003), posebna št., 67-79. - Nekatere razlike v rabi perfektivnega prezenta v slovenščini in ruščini, MSK-13, 233.

Aleksandra Derganc - Ada Vidovič Muha, Глагольные способы выражения посессивности в словенском и русском языках, Slavistična revija 56 (2008), št. 2, 133-147. - Выражение отношения посессивности глаголом в словенском и русском языках, MSK-14, 197-198. 
Aleksandra Derganc - Vanda Babič, Matej Sovič i sačuvan rukopis njegovog latinskog prijevoda gramatike Meletija Smotrickog (1619.) iz 1773. godine u rukopisnoj zbirci NUK Ljubljana, MSK-14, 198-199.

Janez Dular, Poročani govor v slovenskem knjižnem jeziku, MSK-8 , 196.

Tomaž Erjavec, Making Corpora Available, MSK-13, 288-289 (organizator in sodelujoči v tematskem bloku 7: Corpus Linguistics for Slavic Languages).

Metka Furlan, Podaljšava - praslovanski izpridevniški vzorec, Slavistična revija 51 (2003), posebna št., 13-26. — Vokaldehnung - das urslawische deadjektivische Wortbildungsmuster, MSK-13, 234.

Metka Furlan, Interna in eksterna rekonstrukcija v slovanski etimologiji, Slavistična revija 56 (2008), št. 2, 3-16. — Metka Furlan - Alenka Šivic-Dular, Interna rekonstrukcija v slovanski etimologiji, MSK-14, 310-311 (tematski blok 1.7: Аспекты типологических исследований).

Alenka Glaser, Iz poetike slovenske moderne: sestavine ljudske poetike v poeziji slovenske moderne in njihova funkcija v njej, MSK-8 $1,270$.

Helga Glušič, Sodobna slovenska književnost v Ameriki, Slavistična revija 36 (1988), št. 2, 233-237.

Marjetka Golež Kaučič, Teorija in intertekstualnosti in njena uporaba v folklorističnih raziskavah, Slavistična revija 51 (2003), posebna št., 311-328. - Teorija intertekstualnosti in njena uporaba v folklorističnih raziskavah, MSK$13,193-194$.

Igor Grdina, Začetki slovenske književnosti med protestantsko in katoliško reformacijo, Slavistična revija 41 (1993), št. 1, 77-129.

Miran Hladnik, Preštevna določila slovenske povesti, Slavistična revija 41 (1993), št. 1, 65-75.

Miran Hladnik, Ideja slovanstva v slovenski zgodovinski povesti, Slavistična revija 46 (1998), št. 1-2, 117-131. — The Slavic Idea in the Slovene Historical Novel, MSK-12, 232.

Jasna Honzak Jahić, Pohlinov in Metelkov opis slovenskega knjižnega jezika v luči časa njunega nastanka, Slavistična revija 51 (2003), posebna št., 331350. - Pohlinov in Metelkov opis knjižnega jezika v luči časa njunega nastanka, MSK-13, 194.

Marjeta Humar, Contemporary Process in the Field of Slavic Terminology and Terminography, MSK-13, 234-235.

Aleksander Isačenko, Потеря глагольных форм в русском языке, MSK-3 , 56-64.

Barbara Ivančič Kutin, Neslovanske besede v bovškem narečnem besedišču, Slavistična revija 56 (2008), št. 2, 87-101. — Non-slavic words in Bovec dialectal vocabulary, MSK-14, 200.

Franc Jakopin, O deležu ruskih elementov v razvoju slovenskega knjižnega jezika, Slavistična revija 16 (1968), 65-90. — Delež ruskih jezikovnih elementov v razvoju slovenskega knjižnega jezika, MSK-6, 97.

Franc Jakopin, K vprašanju substantivizacije pridevniških besed v slovanskih jezikih, Slavistična revija 21 (1973), št. 2, 265-277. - Substantivizacija pridevnikov in drugih besednih vrst v slovanskih jezikih, MSK-7, 227-228. 
Franc Jakopin, Struktura slovenskih priimkov v statistični osvetlitvi, Slavistična revija (1977), kongresna št., 5-25. — Struktura slovenskih priimkov v statistični osvetlitvi, MSK- 8,373 .

Franc Jakopin, The Specifics of the Slovene Formation of Personal Names within the Frame of Slavic Languages, MSK-9, 110.

Franc Jakopin, Sledovi jezikovnih stikov v slovenski antroponimiji, MSK-12, 246.

Primož Jakopin, The Possible and Actual Size of Slovenian Wordform Vocabulary, MSK-13, 235-236.

Miha Javornik, Internet - začetek novega ali ponavljanje znanega? (Kaj pri tem počne Mihail Bahtin?), Slavistična revija 46 (1998), št. 1-2, 141-152. Aspects of Communication in Internet Era, MSK-12, 232-233.

Miha Javornik, Ogroženost meje: način rušenja nacionalnega kulturnega modela, MSK-13, 194-195.

Marko Jesenšek, Prekmurska publicistika 19. stoletja in prve polovice 20. stoletja med knjižno normo in tradicijo, Slavistična revija 56 (2008), št. 2, 103-113. Schriftsprache in publizistischen Texten in Prekmurje im 19. und in der ersten Hälfte des 20. Jh.: Sprache zwischen Standard und Dialekt, MSK-14, 200-201.

Niko Jež, Walenrodizem in črtomirstvo: idejne preobrazbe dveh literarnih mitov, MSK-13, 195.

Janko Jurančič, O priimkih pri južnih Slovanih, Slavistična revija (1977), kongresna št., 27-39. — O priimkih pri južnih Slovanih, MSK-8 , 394.

Marko Juvan, Heideggerjanski kod slovenskega modernizma, MSK-12, 233.

Marko Juvan, Stil in identiteta literarnega besedila, MSK-13 ${ }_{2}, 195-196$.

Majda Kaučič Baša, The Maintenance and Shift of Slovenian: The Case of the Autochtonous Slovenian Minorities in Italy, Austria and Hungary, MSK-13, 236.

France Kidrič, Dobrovský et la renaissance littéraire slovène de son temps, MSK$1_{2}, 851-852$. - Dobrovský in slovenski preporod njegove dobe, Ljubljana, 1930 (Razprave Znanstvenega društva v Ljubljani 7: historični odsek 1).

Matjaž Kmecl, Slovenska partizanska spominska proza, MSK-8, 431.

Gregor Kocijan, Značilnosti Prešernove, Puškinove in Mickiewiczeve balade razhajanja in podobnosti (problemska skica), Slavistična revija 51 (2003), posebna št., 193-210. — Značilnost Prešernove, Puškinove in Mickiewiczeve balade - razhajanje in podobnosti, MSK-13, 196.

Rudolf Kolarič, Jezikovni pouk materinega jezika v osnovni in srednji šoli glede na naše učne načrte, MSK-3 ${ }_{4}, 133-139$.

Rudolf Kolarič, [odgovor na vprašanje] Cilj predavanja narodnog jezika (vladanje književnim jezikom, poznavanje jezičke građe, poznavanje jezika uopšte), MSK-3, 175-176.

Rudolf Kolarič, Periodizacija razvoja slovenskega jezika, Slavistična revija 11 (1958), št. 1-2, 69-77. — Periodizacija razvoja slovenskega jezika, Južnoslovenski filolog 23 (1958), št. 1-4, 17-21.

Mihaela Koletnik, Glasoslovni razvoj v slovenskogoriškem narečju, Slavistična revija 51 (2003), posebna št., 37-50. - Glasoslovni razvoj v slovenskogoriškem narečju, MSK-13, 236-237. 
Mihaela Koletnik, O prekmurskih mikrotoponimih, Slavistična revija 56 (2008), št. 2:75-86. — Zu den Mikrotoponyme aus dem Übermurgebiet/Prekmurje, MSK-14, 201-202.

Jože Koruza, Razmerja med slovenskim ustnim, zapisanim in tiskanim slovstvom v starejših obdobjih, MSK- $8_{1}, 449$.

Jože Koruza, Проблемы периодизации древней словенской литературы в типологическом сопоставлении с другими славянскими литературамы, MSK-9, 266-267.

Boža Krakar Vogel, Nekatere značilnosti pouka literature v slovenski šoli - vsebine, cilji in vplivi nanje, MSK-13, 326-327 (organizatorica in sodelujoča v tematskem bloku 17: Slovanski jeziki in književnosti v izobraževanju).

Simona Kranjc, Izražanje prostora v govorjenih besedilih otrok, Slavistična revija 51 (2003), posebna št., 181-190. — Izražanje prostora v govorjenih besedilih, MSK-13, 237.

Bratko Kreft, Fragmenti o slovensko-ruskih stikih, Slavistična revija 11 (1958), št. $1-2,90-108$.

Bratko Kreft, Dostojevski in utopični socializem, Slavistična revija 14 (1963), 1-24.

Bratko Kreft, Tradicija in avantgarda, Slavistična revija 16 (1968), 91-158. Авантгардизм и традиционализм, MSK-6, 259.

Bratko Kreft, Kafka in ruska književnost, MSK-7, 726-727.

Bratko Kreft, Turgenew und Marko Wowtschok, MSK-9, 302-303.

Martina Križaj Ortar, Predmet slovenščina z novimi učnimi načrti, MSK-13, 328 (tematski blok 17: Slovanski jeziki in književnosti v izobraževanju).

Tine Logar, O izgubi nominalnih končnic v nekaterih slovenskih primorskih govorih, Slavistična revija 11 (1958), št. 1-2, 109-112. - O izgubi nominalnih končnic v nekaterih slovenskih primorskih govorih, Južnoslovenski filolog 23 (1958), št. 1-4, 35-37.

Tine Logar, Sistemi dolgih vokalnih fonemov v slovenskih narečjih, Slavistična revija 14 (1963), 111-132.

Tine Logar, Glasoslovne in morfološke posebnosti v govorici sloveniziranih Nemcev, Slavistična revija 16 (1968), 159-168. — Glasoslovne in morfološke posebnosti v govorici sloveniziranih Nemcev, MSK-6 111.

Tine Logar, Slovenska dialektična metatonija, Slavistična revija (1977), kongresna št., 41-45 (sekcijski referat in častno predavanje na zasedanju v Ljubljani). - Slovenska dialektična metatonija, MSK-8 $2,512$.

Milko Matičetov, Pregled ustnega slovstva Slovencev v Reziji (Italija), Slavistična revija 16 (1968), 203-229. — Folklora Slovencev v Reziji (Italija) - preizkusni kamen slovenske folkloristike, MSK-6, 363.

Majda Merše, Vrste glagolskega dejanja v delih slovenskih protestantskih piscev 16. stoletja in tuje prevodne predloge, Slavistična revija 46 (1998), št. 1-2, 55-71. - Vrste glagolskega dejanja v delih slovenskih protestantskih piscev 16. stoletja in tuje prevodne predloge, MSK-12, 247.

Majda Merše, Glagolski kalki v zgodovini slovenskega knjižnega jezika (prevzemanje, raba in primerjava s stanjem v slovanskih jezikih), Slavistična revija 
51 (2003), posebna št., 81-103. - Verbale Lehnübersetzungen in der Geschichte der slowenischen Standardsprache (Übernehmen, Gebrauch und Vergleich mit der Situation in den anderen slawischen Sprachen), MSK-13, 238-239.

Janko Moder, Tolstojeva povest v treh slovenskih prevodih, Slavistična revija (1977), kongresna št., 47-81. — Lev N. Tolstoj v zgodnjih slovenskih prevodih, MSK- ${ }_{2}, 605$.

France Novak, Samostalniška večpomenskost v knjižni slovenščini 16. stoletja glede na prevodne zglede, Slavistična revija 46 (1998), št. 1-2, 83-94. - Samostalniška večpomenskost $\mathrm{v}$ knjižni slovenščini 16 . stoletja in $\mathrm{v}$ prevodnih zgledih, MSK-12, 247-248.

France Novak, Terminologija v odvisnosti od jezikoslovnih in družbeno-političnih dejstev, MSK-13, 239.

Irena Orel, Josef Dobrovský in slovenski slovničarji - vzporednosti in različnosti v oblikoslovnih prikazih, Slavistična revija 51 (2003), posebna št., 351-373. - Josef Dobrovský in slovenski slovničarji - vzporednosti in različnosti v oblikoslovnih prikazih, MSK-13 $2,196-197$.

Irena Orel, Grammatik der slavischen Sprache in Krain, Kärnten und Steyermark (1808) Jerneja Kopitarja in Primož Trubar, Slavistična revija 56 (2008), št. $2,115-132$.

Martina Orožen, Adverbializacija (morfologizacija) odvisnikov v slovenskem diahroničnem jezikovnem razvoju, MSK- $8,655$.

Martina Orožen, Kontinuiteta starocerkvenoslovanskega besedišča v slovenskem jeziku, Slavistična revija 41 (1993), št. 1, 143-160.

Vladimir Osolnik, Romantičarski nacionalni epovi i nacionalni identitet Južnih Slovena, Slavistična revija 56 (2008), št. 2, 179-190. — Romantične pesnitve in nacionalna identiteta pri Južnih Slovanih, MSK-14 $2,187-188$.

Boris Paternu, Nastanek teorije realizma v slovenski književnosti, Slavistična revija 14 (1963), 153-180.

Boris Paternu, Struktura in funkcija Jenkove parodije v razvoju slovenske romantične epike, Slavistična revija 16 (1968), 7-64. - Структура и функция пародии Симона Йенко в процессе разложения словенской романтической эпики, MSK-6, 236. - Funkcije parodije v razvoju slovenske romantične poezije, MSK- $6_{2}, 92$.

Boris Paternu, Recepcija romantike v slovenski poeziji, Slavistična revija 21 (1973), št. 2, 113-148. - Recepcija romantike v slovenski književnosti, MSK-7, 511-512.

Boris Paternu, Poetika slovenskega narodnoosvobodilnega pesništva 1941-1945, Slavistična revija (1977), kongresna št., 161-193 (sekcijski referat in častno predavanje na zasedanju v Ljubljani). — Poetika slovenskega NOB pesništva 1941 do 1945, MSK- $8,675$.

Boris Paternu, Problem realizma in modernizma v povojni slovenski liriki (19451980), Slavistična revija 31 (1983), št. 2, 89-106. - Проблема реализма и модернизма в послевоенной словенской лирике 1945-1975, MSK-9, 274-275. 
Boris Paternu, Poskus tipološkega modeliranja literarne evolucije (Ob slovenskem primeru), Slavistična revija 41 (1993), št. 1, 5-11.

Boris Paternu, Herezija kot vir nadrealizma v poeziji Edvarda Kocbeka, MSK-12, 234.

Boris Paternu, Prešeren na stičišču nemške, italijanske in poljske literature, MSK$13_{2}, 197$.

Dušan Pirjevec, Strukturalna poetika in literarna znanost, Slavistična revija 21 (1973), št. 2, 187-215.

Dušan Pirjevec, F. M. Dostojevski in evropska romaneskna tradicija, MSK-8 $2,698$.

Marija Pirjevec, Problem etnocentrizma in univerzalizma na začetku slovenske književnosti, MSK-12, 234.

Janko Pleterski, Nacionalni problem Slovencev in delavsko gibanje, MSK-8 $2,702$.

Jože Pogačnik, Pojem književne tradicije v znanosti o književnosti, Slavistična revija 41 (1993), št. 1, 55-64.

Breda Pogorelec, Razvoj slovenskega prostega stavka, MSK-6 ${ }_{1}, 54$.

Breda Pogorelec, Slogovni razvoj slovenske besedne umetnosti XX. stoletja, MSK$8,704$.

Breda Pogorelec, Directing Factors in the History of Slovene and Other Slavic Literary Languages, MSK-9 , 219-220.

Breda Pogorelec, Kriterij knjižnosti slovenskega jezika, MSK-13, 239.

Vesna Požgaj Hadži - Marija Smolič, Hrvaško-slovenska leksična homonimija, MSK-12, 248.

Vesna Požgaj Hadži, Hrvatski kao izborni predmet u slovenskoj devetogodišnjoj osnovnoj školi, MSK-13, 328-329 (tematski blok 17: Slovanski jeziki in književnosti v izobraževanju).

Nikolaj F. Preobraženskij, Русские и словенские односоставные предложения, Slavistična revija 11 (1958), št. 1-2, 113-121.

Fran Ramovš, Obči momenti iz razvoja slovenskega jezika, MSK-3 3 , 37-44.

Fran Ramovš, [odgovor na vprašanje] Kako bi se mogla epoha praslovenskog jezika vremenski odrediti?, MSK-3, 15-17.

Fran Ramovš, [odgovor na vprašanje] Da li etimološki rečnik praslovenskog jezika treba da obuhvati semantičku stranu reči u istoriskom razvitku?, MSK-3 , 15-17.

Jakob Rigler, Pregled osnovnih razvojnih etap v slovenskem vokalizmu, Slavistična revija 14 (1963), 25-78.

Jakob Rigler, K problematiki daljšanja starega akuta, Slavistična revija (1977), kongresna št., 83-99.

Janez Rotar, Historična projekcija v sodobnem jugoslovanskem romanu, Slavistična revija 31 (1983), št. 2, 107-115. - Историческая проекция в современном югославском романе, MSK-9, , 278-279.

Mirko Rupel, [odgovor na vprašanje] Da li udžbenici za osnovne i srednje škole treba da budu dvojaki: jedni za učenike, drugi za nastavnike?, MSK-3, 201-203.

Tomaž Sajovic, Slog je pomen, pomen je slog, Ivan Cankar: Edina beseda, Ciril Kosmač: Pomladni dan, Slavistična revija 51 (2003), posebna št., 165-180. - Slog je pomen - pomen je slog, MSK-13, 240.

Aleksander Skaza, Динамическая модель литературной эволюци, MSK-9, 281. 
Aleksander Skaza, Literarni subjekt v pripovedni prozi ruskega simbolizma (na primerih iz romanov Andreja Belega), Slavistična revija 36 (1988), št. 2, 217-231.

Aleksander Skaza, »Pesniška gramatika« Andreja Belega in problemi poetike romana Peterburg, MSK-12, 235.

Aleksander Skaza, Avtor, siže in dekanonizacija žanra romana Peterburg Andreja Belega in poema Bronasti jezdec A. S. Puškina, MSK-13 ${ }_{2}, 197-199$.

Anton Slodnjak, Slovenska romantična poezija (1830-1848) v odnosu do slovanskih in neslovanskih literatur, Slavistična revija 11 (1958), št. 1-2, 1-18.

Vera Smole - Melita Zemljak, Pogostnost in trajanje nenaglašenih in izvorno o-jevskih samoglasnikov v nekaterih slovenskih akajočih in ukajočih govorih (Instrumentalno-slušna analiza), Slavistična revija 51 (2003), posebna št., 51-65. - Pogostnost in trajanje nenaglašenih in izvorno o-jevskih samoglasnikov v nekaterih slovenskih akajočih in ukajočih govorih (Instrumentalno-slušna analiza), MSK-13, 243-244.

Vera Smole, Geolingvistična predstavitev izbranih frazemov s sestavino roka v slovenskih narečjih, Slavistična revija 56 (2008), št. 2, 49-73. - Geolingvistički prikaz izabranih frazema sa sastavnicom »ruka « u slovenskim dijalektima i njihova potvrđenost u slavenskim i njima bliskim jezicima, MSK-14, 203-204.

Marija Smolič - Vesna Požgaj Hadži, Hrvaško-slovenska leksična homonimija, MSK- $12,248$.

Vid Snoj, Razsvetljeni Juda: novozavezni ciklus Vodnika, MSK-13, , 199-200.

Marko Stabej, Slovenian: Small is Beautiful, MSK-14, 283 (tematski blok 5: Inter-Slavica).

Marija Stanonik, Mythology and Literary Folklore, MSK-12, 235.

Marija Stanonik, Slavistična folkloristika (po slovensko), MSK-13 , 334-335 (tematski blok 17: Folklór a folkloristika na prelome milénia).

Marija Stanonik, Svetopisemska motivika v slovenskem leposlovju 19. in 20. stoletja, Slavistična revija 51 (2003), posebna št., 261-307. — Svetopisemska motivika v slovenskem leposlovju, MSK-13, 201.

Marija Stanonik, The religious aspect of Slavic literary folklore, MSK-14, 204.

Dragi Stefanija, Эволюционные процессы в развитии македонского литературного языка и других славянских языков, Slavistična revija 31 (1983), št. 2 , 117-122. - The Developmental Processes of Literary Macedonian in Relation to Other Slavic Languages, MSK-9, 221-222.

France Stele, Okras staroslovenskih iluminiranih rokopisov Državne študijske v Ljubljani [registrirano samo v kongresnem programu], MSK-2.

Aleksandar Stojičević, Za uvaženje Kašićeve i Bohoričeve gramatike, MSK-3 ${ }_{3}, 62-64$.

Irena Stramljič Breznik, Besedotvorna tipologija novonastalega besedja s področja mobilne telefonije, Slavistična revija 51 (2003), posebna št., 105-118. Besedotvorna tipologija novonastalega besedja s področja mobilne telefonije, MSK-13, 240.

Irena Stramljič Breznik, Prevzete leksemske prvine in njihova besedotvorna zmožnost v slovenščini, Slavistična revija 56 (2008), št. 2, 149-160. — Fremde lexikalische Elemente und ihre Wortbildungspotenz im Slowenischen, MSK$14_{1}, 204-205$. 
Alenka Šivic-Dular, Iz problematike glagolov rekanja v slovanskih jezikih, MSK8,866 .

Alenka Śrivic-Dular, To the Origine of some Slavic Declensional Types, MSK-9, 74.

Alenka Šivic-Dular, Kontrakcija v slovanskih jezikih, Slavistična revija 46 (1998), št. 1-2, 5-43. - Kontrakcija v slovanskih jezikih, MSK-12, 248.

Alenka Šivic-Dular, Razvoj pridevniških sklanjatev v kontekstu zgodovinskih in arealnih vidikov, Jezikoslovni zapiski 9 (2003), št. 2, 7-28. — The Evolution of Adjectival Declension in the Light of Historical and Areal Aspects, MSK-13, 241.

Božo K. Škerlj, Rasni tipi Slovencev, Księga referatów: sekcja III: kulturalno-społeczna-sekcja I: dydakticzna, Warszawa, 1934, 84-88.

Emil Štampar, Odjek ruske revolucije 1905 na Kranjčevića, Slavistična revija 11 (1958), št. 1-2, 78-89.

Emil Štampar, Radnik u djelima hrvatskih realista, Slavistična revija 14 (1963), 133-152.

Miran Štuhec, Motivno-tematska raven pripovedne proze slovenskih izseljencev v Avstraliji (razvojni premiki), Slavistična revija 46 (1998), št. 1-2, 133-140. - Motivačně-tématická úroveň výpravné prozy slovinských vystěhovalců v Australii, MSK-12, 236.

Nace Šumi, Slovenska likovna kultura in zgodovinopisje v dvajsetem stoletju, MSK-8, 874 .

Peter Tancig, Računalniški model transformacijske slovnice slovenskega jezika = A Computer Model of transformational Grammar of Slovene language, MSK- $8_{2}, 878$.

Marko Terseglav, Folkloristika v sožitju in v nasprotju z literarno zgodovino, MSK-13, 201-202.

France Tomšič, [odgovor na vprašanje] Staroslovenski jezik i istoriski razvitak narodnog jezika u srednjoškolskoj nastavi, MSK-3 , 197-198.

France Tomšič, Podoba najstarejše pisne slovenščine, Slavistična revija 11 (1958), št. 1-2, 19-34.

Jože Toporišič, Stilna vrednost glasoslovnih, prozodijskih, (pravo)pisnih, morfemskih in naglasnih variant slovenskega knjižnega jezika, Slavistična revija 21 (1973), št. 2, 217-263. - Stilno zaznamovana glasovna, pisna, naglasna in oblikoslovna sredstva slovenskega knjižnega jezika, MSK-7, 292-293.

Jože Toporišič, Mali jezik v večjezikovni državni skupnosti s stališča zgodovine slovenskega knjižnega jezika, Slavistična revija (1977), kongresna št., 101114. — Problemi malega jezika v večjezikovni državi, MSK- $8_{2}, 899$.

Jože Toporišič, Zveneči ustnični nenosni nezaporniški soglasniki v slovanskih jezikih, Slavistična revija 31 (1983), št. 2, 123-143. - The Phoneme [v] in the Consonant Systems of Slavic Standard Languages, MSK-9 ${ }_{1}, 194-195$.

Jože Toporišič, Tvorbeni model slovenskega knjižnega naglasa, Slavistična revija 36 (1988), št. 2, 133-180.

Jože Toporišič, Periodizacija slovenskega knjižnega jezika, Slavistična revija 41 (1993), št. 1, 131-141.

Jože Toporišič, Eksperimentalnofonetične raziskave slovenskega knjižnojezikovnega glasovja in tonemskosti, Slavistična revija 51 (2003), posebna št., 
119-140. - Eksperimentalnofonetične raziskave slovenskega knjižnojezikovnega glasovja in fonemskosti, MSK-13, 241-242.

Silvo Torkar, Slovenska zemljepisna imena, nastala iz slovanskih antroponimov, Slavistična revija 56 (2008), št. 2, 17-29. - Словенские географические названия, возникшие из славянских антропонимов: состояние исследований и проблемы идентификации, MSK-14, $205-206$.

Silva Trdina, [odgovor na vprašanje] Posebni cilji nastave jezika i književnosti u nižim razredima srednjih škola, MSK-3, 181-184.

Ada Vidovič Muha, Slovene Compounds and their Counterparts in Other Languages, MSK-9, 146.

Ada Vidovič Muha, Skladenjska tipologija zloženk slovenskega knjižnega jezika (Ob kontrastivni naslonitvi na nemške zloženke), Slavistična revija 36 (1988), št. 2, 181-193.

Ada Vidovič Muha, Glagolske sestavljenke - njihova skladenjska podstava in vezljivostne lastnosti (Z normativnim slovensko-nemškim vidikom), Slavistična revija 41 (1993), št. 1, 161-192.

Ada Vidovič Muha, Družbeno-politični vidik normativnosti v slovanskih knjižnih jezikih, Slavistična revija 46 (1998), št. 1-2, 95-116. - Динамика нормативных критериев в современных славянских языках на опыте словенского языка, MSK-12, 352-353 (tematski blok 15: Zmeny v súčasných slovanských jazykoch 1945-1995).

Ada Vidovič Muha - Aleksandra Derganc, Глагольные способы выражения посессивности в словенском и русском языках, Slavistična revija 56 (2008), št. 2, 133-147. - Выражение отношения посессивности глаголом в словенском и русском языках, MSK-14, 197-198.

Valens Vodušek, Folklora Slovencev v Reziji (Italija) - preizkusni kamen slovenske folkloristike, MSK-6, 364.

Janez Vrečko, Kosovel in ruski literarni center konstruktivistov, Slavistična revija 51 (2003), posebna št., 225-240. — Ruski literarni konstruktivizem in Kosovelovi konsi, MSK-13 2 , 202-203.

Franc Zadravec, Slovenska satira v dvajsetem stoletju, Slavistična revija 21 (1973), št. 2, 149-185. — Slovenska slovstvena satira XX. stoletja, MSK-7, 787-788.

Franc Zadravec, Simbolizem v literaturi Ivana Cankarja, Slavistična revija (1977), kongresna št., 195-215. — Simbolizem in slovenska literatura, MSK-8 $2,968$.

Franc Zadravec, »Socialistični realizem《 - zares že leta 1897?, Slavistična revija 31 (1983), št. 2, 145-151. - Социалистический реализм и словенская литература, MSK-9, 284-285.

Franc Zadravec, Srečko Kosovel (1904-1926) in ruski pesniški konstruktivizem podobnosti in razločki, Slavistična revija 36 (1988), št. 2, 195-216.

Franc Zadravec, Recepcija vzhodno- in zahodnoslovanskih literatur na Slovenskem od 1918 do 1940 - soglasja in nasprotja, Slavistična revija 41 (1993), št. $1,25-54$.

Franc Zadravec, Slovenski roman ob koncu XX. stoletja, MSK-12, 236. 
Franc Zadravec, Hudodelec v slovenskem romanu XX. stoletja, Slavistična revija 51 (2003), posebna št., 241-249. - Slovenski roman v drugi polovici 20. stoletja, MSK-13, 203.

Melita Zemljak - Vera Smole, Pogostnost in trajanje nenaglašenih izvorno o-jevskih samoglasnikov v nekaterih slovenskih akajočih in ukajočih govorih (Instrumentalno-slušna analiza), Slavistična revija 51 (2003), posebna št., 51-65. - Pogostnost in trajanje nenaglašenih in izvorno o-jevskih samoglasnikov v nekaterih slovenskih akajočih in ukajočih govorih (Instrumentalno-slušna analiza), MSK-13, 243-244.

Zinka Zorko, Daljšanje akuta v severovzhodnih slovenskih narečjih, Slavistična revija 41 (1993), št. 1, 193-207.

Alojzija Zupan Sosič, Žanrski sinkretizem sodobnega slovenskega romana, Slavistična revija 51 (2003), posebna št., 251-260. — Genre Syncretism of Contemporary Slovenian Novel, MSK-13, 203-204.

Andreja Žele, Slovenska skladnja z vidika skladenjskih teorij, Slavistična revija 51 (2003), posebna št., 141-163. — Slovenska skladnja z vidika skladenjskih teorij, MSK-13, 244.

Andreja Žele, Reševanje nekaterih skladenjskih vprašanj v slovenščini glede na razpoložljive teorije in metode, Slavistična revija 56 (2008), št. 2, 161-176. - Solving some Syntactic Questions in Slovene in Light of Available Theories and Methods, MSK-14, 199-200.

\section{Krajšave}

MSK-1 ${ }_{2}=$ Sborník praci I. sjezdu slovanských filologů v Praze 1929 II: prednášky, uspořádali Jiří Horák - Matyáš Murko - Miloš Weingart - Stanislav Petíra, Praha, 1932.

MSK-2 = II. mezinárodní sjezd slavistů Warszawa 1934: bibliografie, sestavila Eva Velinská a kolektiv, věnováno VII. Mezinárodnímu sjezdu slavistů ve Varšavě 1973, Praha: Statní knihovna České socialistické republiky - Slovanská knihovna, 1972.

MSK-3 = III. mezinárodní sjezd slavistio (slovanských filologů) Ljubljana - Beograd-Zagreb 18.-25. 9. 1939: bibliografie, sestavila Eva Velinská, Praha: Statní knihovna České socialistické republiky - Slovanská knihovna, 1978.

MSK-3 ${ }_{1-5}=$ III međunarodni kongres slavista (slovenskih filologa): Beograd, 1825 IX 1939, Beograd: Izdanja izvršnog odbora, 1939. Vsebuje: Zbirka odgovora na pitanja $=$ Réponses aux questions (No 1), Saopštenja i referati = Communications et rapports (No 2), Dopune = Supplément (No 3), Govori i predavanja $=$ Discours et conférences (No 4), Organizacija = Organisation (No 5). (Ponatis: III međunarodni kongres slavista (slovenskih filologa): Beograd, 18-25 IX 1939, reprint-izdanje materijala neodržanog kongresa, Beograd: Slavističko društvo Srbije, 2008.) 
MSK-6 = VI. mezinárodni sjezd slavistů v Praze 1968: resumé prednášek, prispěvků a sdělení, Mezinárodní komitet slavistů, Praha: Academia - Nakladatelství Československé akademie věd, 1968.

MSK-6 ${ }_{2}=$ Program VI mezinárodiho sjezdu slavistů: 7.-13. VIII. 1968, Praha, 1968.

MSK-7 = VII Międzynarodowy kongres slawistów: Warszawa 21-27 VIII 1973: streszczenia referatów i komunikatów, Międzynarodowy Komitet Slawistów - Polska Akademia Nauk - Polski Komitet Slawistów, Warszawa: Państwowe Wydawnictwo Naukowe, 1972.

MSK-8 ${ }_{1,2}=$ VIII međunarodni slavistički kongres: Zagreb-Ljubljana 3-9. IX 1978 I-II: sažeci, Zagreb: Međunarodni slavistički centar SR Hrvatske, 1978.

MSK-9 = Резюме докладов и письменных сообщений: IX Международный съезд славистов: Киев сентябрь 1983, Академия наук СССР - Международный комитет славистов - Советский комитет славистов, Москва: Издательство »Наука«, 1983.

MSK-12 = XII Międzynarodowy kongres slawistów: Kraków 27 VIII- 2 IX 1998: streszczenia referatów $i$ komunikatów: językoznawstwo, opracowanie Jerzy Rusek - Janusz Siatkowski - Zbigniew Rusek, Międzynarodowy Komitet Slawistów - Polski Komitet Slawistów, Warszawa: Wydawnictwo Energeia, 1998.

MSK-12 = XII Międzynarodowy kongres slawistów: Kraków 27 VIII - 2 IX 1998: streszczenia referatów i komunikatów: literaturoznawswo, folklorystyka, nauka o kulturze, opracowanie Lucjan Suchanek - Lidia Macheta, Międzynarodowy Komitet Slawistów - Polski Komitet Slawistów, Warszawa: Wydawnictwo Energeia, 1998.

MSK-13 = 13. mednarodni slavistični kongres: Ljubljana, 15.-21. avgust 2003: zbornik povzetkov 1: jezikoslovje, ur. France Novak, izd. Mednarodni slavistični komite - Slovenski slavistični komite, Ljubljana: ZRC SAZU, Založba ZRC, 2003.

MSK-13 $=13$. mednarodni slavistični kongres: Ljubljana, 15.-21. avgust 2003: zbornik povzetkov 2: književnost, kulturologija, folkloristika, zgodovina slavistike - tematski bloki, ur. France Novak - Andreja Žele (tematski bloki), izd. Mednarodni slavistični komite - Slovenski slavistični komite, Ljubljana: ZRC SAZU, Založba ZRC, 2003.

MSK-13 = 13. mednarodni slavistični kongres: Ljubljana, 15.-21. avgust 2003: program, ur. Vanda Babič - Matej Šekli - Silvo Torkar, Ljubljana: Slovenski slavistični komite, 2003.

MSK-14 = XIV меѓународен славистички конгрес: Охрид, 10-16 септември 2008: сборник на резимеа I: лингвистика, ур. Снежана Велковска, Скопје: Македонски славистички комитет, 2008.

MSK-14 $4_{2}$ XIV меѓународен славистички конгрес: Охрид, 10-16 септември 2008: сборник на резимеа II: книжевност, култура, фолклор, история на славистика - тематски блокови, ур. Науме Радически - Снежана Венковска-Антевска (тематски блокови), Скопје: Македонски славистички комитет, 2008. 